\title{
X-14766A, A HALOGEN CONTAINING POLYETHER ANTIBIOTIC PRODUCED BY STREPTOMYCES MALACHITOFUSCUS SUBSP. DOWNEYI ATCC 31547 \\ DISCOVERY, FERMENTATION, BIOLOGICAL PROPERTIES AND TAXONOMY OF THE PRODUCING CULTURE
}

\author{
Chao-min liu, Theron E. Hermann, Barbara la T. Prosser, \\ Norberto J. Palleroni, John W. Westley \\ and PhILIP A. MILler \\ Chemical Research Department, Hoffmann-La Roche Inc. \\ Nutley, New Jersey 07110, U.S.A. \\ (Received for publication November 5, 1980)
}

\begin{abstract}
$\mathrm{X}-14766 \mathrm{~A}$ is a novel, chlorine containing polyether antibiotic produced by Streptomyces malachitofuscus subsp. downeyi. The antibiotic is active in vitro against Gram-positive bacteria and is capable of complexing and transporting monovalent as well as divalent metal cations.
\end{abstract}

As part of our search for new antibiotics from soil microorganisms, a Streptomyces strain was found to produce a chlorine containing antibiotic which we designated X-14766A (Fig. 1). This report presents the taxonomy of the producing culture, fermentation condition for the antibiotic production, and biological as well as ionophore properties of X-14766A. The isolation and characterization of the antibiotic are described in the accompanying paper ${ }^{1}$.

Fig. 1. The structure of $\mathrm{X}-14766 \mathrm{~A}$.

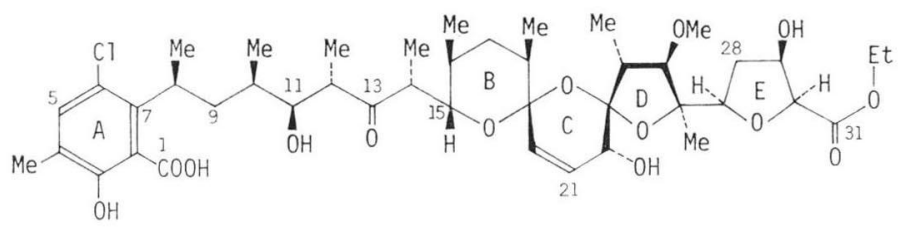

Taxonomy of the Producing Organism

Streptomyces sp. X-14766 was isolated from a sand sample collected from Playa Blanca, Mexico in 1976. The culture has been deposited at the Northern Regional Research Laboratory, Peoria, Illinois and the American Type Culture Collection, Rockville, Maryland, where it has been assigned the numbers NRRL 11335 and ATCC 31547 respectively. The culture resembles the type strain of Streptomyces malachitofuscus (ATCC 25471) in phenotypic properties. It produces a substrate mycelium which does not fragment into spores, and an aerial mycelium forming spiral chain of spores with $15 \sim 20$ spores per chain. Spores are spiny and range in size from $1.2 \times 1.0 \mu \mathrm{m}$ to $1.1 \times 0.73 \mu \mathrm{m}$ (Fig. 2). The cell wall contains the LL-isomer of diaminopimelic acid which, together with the above characteristics, places this organism in the genus Streptomyces ${ }^{2)}$. The growth characteristics of strain X-14766 (ATCC 31547) are summarized in Table 1. The morphological and physiological properties 
Fig. 2. Spiny spores of Streptomyces sp. X-14766 after 14 days of incubation on ISP-2 agar at $28^{\circ} \mathrm{C}$.

Spores were treated with glutaraldehyde, then ethanol, and subjected to critical point drying. Scanning electron micrograph. $45^{\circ}$ angle.

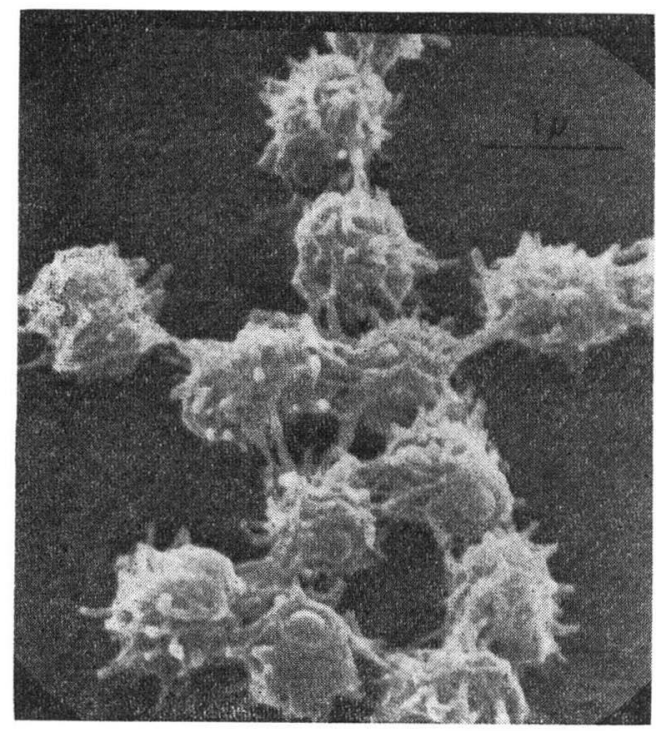

of the strain in comparison with those of the type strain of $S$. malachitofuscus ATCC 25471 are presented in Table 2.

A comparison of the properties of strain X-14766 with S. malachitofuscus ATCC 25471 indicates the close resemblance of these two strains. However, in view of the difference in spore morphology (spiny, instead of spiny/hairy, spores for ATCC 31547) and antibiotic production between the two cultures, we proposed the new designation $S$. malachitofuscus subsp. downeyi for the strain X-14766 after ARTHUR DOWNEY who isolated the organism.

\section{Fermentation}

The vegetative inoculum of X-14766A producing culture was developed by transferring spores of $S$. malachitofuscus subsp. downeyi ATCC 31547 to a $500-\mathrm{ml}$ Erlenmeyer flask containing

$100 \mathrm{ml}$ of an inoculum medium with the following composition (in $\mathrm{g} /$ liter): Tomato pomace 5.0, distillers soluble 5.0, O.M. peptone (Oscar Meyer \& Co., Madison, Wis.) 5.0, debittered dried yeast 5.0, cornstarch 20.0, $\mathrm{CaCO}_{3} 1.0$, and $\mathrm{K}_{2} \mathrm{HPO}_{4}$ 1.0. The $\mathrm{pH}$ of the medium was adjusted to 7.0 before autoclaving. The inoculated flask was incubated for 72 hours at $28^{\circ} \mathrm{C}$ on a rotary shaker operating at $250 \mathrm{rpm}$. Three $\mathrm{ml}(3 \%, \mathrm{v} / \mathrm{v})$ of the resulting vegetative growth were used to inoculate a 500-ml Erlenmeyer flask containing $100 \mathrm{ml}$ of the following medium (in $\mathrm{g} /$ liter): Glucose 10.0, molasses (Black strap) 20.0, HySoy T (Hunko Sheffield Chemical Co., Lyndhurst, N. J.) 5.0, and

Table 1. Cultural characteristics of Streptomyces malachitofuscus subsp. downeyi ATCC 31547.

\begin{tabular}{|c|c|c|c|}
\hline Agar medium & $\begin{array}{l}\text { Amount of growth; } \\
\text { Degree of sporulation }\end{array}$ & Spore mass color ${ }^{\mathrm{a}}$ & $\begin{array}{l}\text { Color of reverse- } \\
\text { substrate myceliuma }\end{array}$ \\
\hline Yeast malt extract (ISP-2) ${ }^{b}$ & $\begin{array}{l}\text { Abundant growth; } \\
\text { well sporulated }\end{array}$ & $\begin{array}{l}2 i h \text { (dark covert gray) } \\
\text { mostly; } 2 f e \text { (covert } \\
\text { gray) at edge }\end{array}$ & $\begin{array}{l}2 g e \text { (covert tan) mostly; } \\
2 l i \text { (covert brown) }\end{array}$ \\
\hline Oatmeal (ISP-3) ${ }^{b}$ & $\begin{array}{l}\text { Abundant growth; } \\
\text { well sporulated }\end{array}$ & $3 f e$ (silver gray) & $2 e c$ (biscuit) \\
\hline $\begin{array}{l}\text { Inorganic salts starch } \\
\left({\text { ISP-4 })^{\mathrm{b}}}^{\mathrm{m}}\right.\end{array}$ & $\begin{array}{l}\text { Moderate growth; } \\
\text { well sporulated; } \\
\text { hydrolyzes starch }\end{array}$ & $\begin{array}{l}2 f e \text { (covert gray); } \\
\text { edges of } b \text { (oyster } \\
\text { white) }\end{array}$ & $\begin{array}{l}2 g c \text { (bamboo), trace of } \\
1 \frac{1}{2} i e \text { (light olive) }\end{array}$ \\
\hline Glycerol asparagine $\left(\right.$ ISP-5) ${ }^{\mathrm{b}}$ & $\begin{array}{l}\text { Moderate growth; } \\
\text { moderate sporulation }\end{array}$ & $2 d c$ (natural string) & $2 g c$ (bamboo) \\
\hline CZAPLK-DOX & $\begin{array}{l}\text { Moderate growth; } \\
\text { sparse sporulation }\end{array}$ & $2 d c$ (natural string) & 2ie (light mustard tan) \\
\hline
\end{tabular}

s Color determinations were made after two weeks of incubation at $28^{\circ} \mathrm{C}$. Color scheme used was that taken from the Color Harmony Manual, 4th ed., 1958, Container Corporation of America, Chicago.

b Media recommended by the International Streptomyces Project ${ }^{32}$.

c Czapek-Dox broth (BBL) to which $1.5 \%$ agar was added. 
Table 2. Comparison of morphological and physiological characteristics of strain ATCC 31547 and ATCC 25471.

\begin{tabular}{|c|c|c|}
\hline Test ${ }^{\mathrm{a}}$ & ATCC $31547(X-14766)$ & $\begin{array}{l}\text { S. malachitofuscus } \\
\text { ATCC } 25471\end{array}$ \\
\hline ISP-6 darkening & + & + \\
\hline Melanin, ISP-7 & + , variable & - \\
\hline Casein hydrolysis ${ }^{b}$ & + & + \\
\hline Gelatin hydrolysis ${ }^{c}$ & \pm & + \\
\hline Starch hydrolysis ${ }^{\mathrm{d}}$ & + & + \\
\hline $\mathrm{NaCl}(\%)$ tolerance ${ }^{\mathrm{b}}$ & $<5$ & 7 \\
\hline Growth range temp. $\left({ }^{\circ} \mathrm{C}\right)$ & $28 \sim 45$ & $\geq 10 \sim 45$ \\
\hline ISP-1 darkening & + & + \\
\hline Reverse-side pigment & none & none \\
\hline Soluble pigment & none & none \\
\hline Antibiotic production & $\mathrm{X}-14766 \mathrm{~A}$ & anti-bacterial \\
\hline Nitrate reduction ${ }^{\mathrm{b}}$ & - & - \\
\hline Hygroscopic property & + , variable & - \\
\hline Spore chain form $/ \#$ spores per chain & spira/15 20 & $\mathrm{RA}$ to spira $/ 15 \sim 25$ \\
\hline Spore surface & spiny & spiny/hairy ${ }^{\text {f }}$ \\
\hline \multicolumn{3}{|l|}{ Carbon utilization tests ${ }^{\mathrm{e}}$} \\
\hline D-Glucose & H & H \\
\hline D-Xylose & + & $+(+)$ \\
\hline L-Arabinose & H & H \\
\hline L-Rhamnose & \# & H \\
\hline D-Fructose & H & H \\
\hline D-Galactose & $+(+)$ & H \\
\hline Raffinose & - & - \\
\hline D-Mannitol & H & H \\
\hline$i$-Inositol & H & H \\
\hline Salicin & \pm & + \\
\hline Sucrose & H & $+(+)$ \\
\hline Cellulose & - & - \\
\hline
\end{tabular}

a All tests were run at $28^{\circ} \mathrm{C}$.

b Test was done by method recommended in reference (4).

c See reference (5) for the test.

d Determination was made, after growth on agar of Actinomyces broth (Difco) with $0.25 \%$ soluble starch, by flooding the plates with iodine-KI solution.

e - , Negative response; \pm , doubtful response; + , more growth than on carbon control but less than on glucose; $+(+)$, growth almost equal to glucose; $\#$, positive response equal to glucose. Tests performed on carbon utilization agar (Bacto ISP-9) containing $1.0 \%$ of the indicated carbon source.

f Data obtained from reference (6).

$\mathrm{CaCO}_{3}$ 2.0. The $\mathrm{pH}$ of the medium was adjusted to $7.2(\mathrm{NaOH})$ before autoclaving. The fermentation was carried out for 5 days at $28^{\circ} \mathrm{C}$ on a rotary at $250 \mathrm{rpm}$. Time course of a typical X-14766A fermentation in shake flask is shown in Table 3.

For tank fermentation, 6 liters of inoculum growth prepared as described above was used to start the fermentation in a 100-gallon fermentor containing 60 gallons of medium with the following composition (in g/liter): Cerelose 10.0, molasses (Black strap) 20.0, HySoy T (Hunko Sheffield 
Table 3. Fermentation production of X-14766A in shake flask.

\begin{tabular}{c|l|c}
\hline Day & $\mathrm{pH}$ & Potency $(\mu \mathrm{g} / \mathrm{ml})$ \\
\hline 1 & 7.1 & - \\
2 & 7.0 & 7 \\
3 & 6.85 & 28 \\
4 & 7.2 & 56 \\
5 & 7.45 & 64
\end{tabular}

Fermentation was carried out as described in the text. Antibiotic potency in broth was estimated by an assay against Staphylococcus aureus ATCC 6538P using an agar diffusion method.

Table 4. In vitro antimicrobial activity of antibiotic X-14766A.

\begin{tabular}{|c|c|}
\hline Organism & $\begin{array}{c}\mathrm{MIC} \\
(\mu \mathrm{g} / \mathrm{ml})^{*}\end{array}$ \\
\hline Pseudomonas aeruginosa ATCC 8705 & $>100$ \\
\hline Proteus vulgaris ATCC 6380 & $>100$ \\
\hline Escherichia coli ATCC 27856 & $>100$ \\
\hline Klebsiella pneumoniae ATCC 27858 & $>100$ \\
\hline Serratia marcescens ATCC 27857 & $>100$ \\
\hline Serratia sp. ATCC 93 & $>100$ \\
\hline $\begin{array}{l}\text { Acinetobacter calcoaceticus } \\
\text { ATCC } 10153\end{array}$ & $>100$ \\
\hline Staphylococcus aureus ATCC 6538P & 0.01 \\
\hline Sarcina lutea ATCC 9341 & 0.03 \\
\hline Bacillus megaterium ATCC 8011 & 0.03 \\
\hline Bacillus sp. E ATCC 27859 & 0.006 \\
\hline Bacillus subtilis NRRL 558 & 0.05 \\
\hline Bacillus sp. TA ATCC 27860 & 0.03 \\
\hline Mycobacterium phlei ATCC 355 & 0.09 \\
\hline Streptomyces cellulosae ATCC 3313 & 0.09 \\
\hline Bacteroides fragilis ATCC 12290 & 0.19 \\
\hline Clostridium histolyticum 503-86 & 0.01 \\
\hline Clostridium septicum 503-34 & 0.01 \\
\hline Paecilomyces varioti ATCC 26820 & $>100$ \\
\hline Penicillium digitatum ATCC 26821 & $>100$ \\
\hline Candida albicans NRRL 477 & $>100$ \\
\hline Saccharomyces cerevisiae ATCC 4226 & $>100$ \\
\hline
\end{tabular}

* Lowest two-fold dilution giving a zone of inhibition in an agar diffusion assay.
Table 5. Displacement of ${ }^{86} \mathrm{Rb}^{+}$and ${ }^{45} \mathrm{Ca}^{2+}$ from X-14766A-cation complexes by other cations.

\begin{tabular}{|c|c|c|c|}
\hline \multirow{2}{*}{$\begin{array}{l}\text { Displacing } \\
\text { cation }\end{array}$} & \multirow{2}{*}{$\begin{array}{l}\text { Cation } \\
\text { radius } \\
(\AA)\end{array}$} & \multicolumn{2}{|c|}{$\begin{array}{l}{ }^{88} \mathrm{Rb}^{+} \text {or }{ }^{45} \mathrm{Ca}^{2+} \text { remain- } \\
\text { ing in complex }(\%)\end{array}$} \\
\hline & & ${ }^{88} \mathrm{Rb}^{+}$ & ${ }^{45} \mathrm{Ca}^{2+}$ \\
\hline none & - & 68 & 70 \\
\hline $\mathrm{Mg}^{2+}$ & 0.82 & 67 & 55 \\
\hline $\mathrm{Ca}^{2+}$ & 1.18 & 68 & 40 \\
\hline $\mathrm{Sr}^{2+}$ & 1.12 & 70 & 37 \\
\hline $\mathrm{Ba}^{2+}$ & 1.34 & 69 & 5 \\
\hline $\mathrm{Li}^{+}$ & 0.68 & 68 & 64 \\
\hline $\mathrm{Na}^{+}$ & 0.97 & 17 & 0.4 \\
\hline $\mathrm{K}^{+}$ & 1.33 & 10 & 0.3 \\
\hline $\mathrm{Rb}^{+}$ & 1.47 & 33 & 1 \\
\hline $\mathrm{Cs}^{+}$ & 1.67 & 52 & 6 \\
\hline
\end{tabular}

The cation selectivity sequence of $\mathrm{X}-14766 \mathrm{~A}$ was determined by the method described previously. ${ }^{12)}$ Two $\mu$ moles of X-14766A (in $2 \mathrm{ml}$ of $70 \%$ toluene$30 \% n$-butanol) were equilibrated by shaking for 2 hours at $20^{\circ} \mathrm{C}$ with $2 \mu$ moles of ${ }^{86} \mathrm{RbCl}$ or $1 \mu$ mole of ${ }^{45} \mathrm{CaCl}_{2}$ (in $1 \mathrm{ml}$ of dimethyl glycinetetramethyl-ammonium hydroxide buffer, $25 \mathrm{~mm}$, $\mathrm{pH}$ 10.0). Complex formation was measured by liquid scintillation counting of both phases (see Fig. 3).

Displacement of labelled cation from the ionophore complexes was determined by the addition of unlabelled cations ( $2 \mu$ moles of monovalent or $1 \mu$ mole of divalent metal chloride).

Chemical Co.)5.0, $\mathrm{CaCO}_{3} 2.0$, and SAG 4130 silicon antifoam (Union Carbide) 0.1. $\mathrm{pH}$ of the medium was adjusted to $7.2(\mathrm{NaOH})$ before sterilization. The tank was stirred at an impeller speed of $280 \mathrm{rpm}$ and aerated at 3 cubic feet per minute. The fermentation was harvested after 5 days of incubation at $28^{\circ} \mathrm{C}$.

\section{Biological and Ionophorous Properties}

Like other polyether antibiotics, $\mathrm{X}-14766 \mathrm{~A}$ is primarily active against Gram-positive bacteria and some anaerobes (Table 4). In addition, it exhibits in vitro activity against several strains of Treponema hyodysenteriae, a causal agent of swine dysentery (MIC: $0.02 \sim 0.04 \mu \mathrm{g} / \mathrm{ml}$ ), and is active as an antimalarial agent with an $\mathrm{ED}_{50}$ of $2.5 \mathrm{mg} / \mathrm{kg}$ against Plasmodium bergei in mice. The $\mathrm{LD}_{50}$ for $\mathrm{X}-14766 \mathrm{~A}$ in mice is $350 \mathrm{mg} / \mathrm{kg}$, p.o. and $5.75 \mathrm{mg} / \mathrm{kg}$, i.p. The antibiotic is also effective in stimulating the production of propionic acid in an in vitro rumen fermentation ${ }^{7)}$. 
Table 6. Cation selectivity sequence of X-14766A and other ionophorous antibiotics.

\begin{tabular}{|c|c|}
\hline Ionophore & Cation selectivity sequence \\
\hline$X-14766 A$ & $\begin{array}{l}\mathrm{K}^{+}>\mathrm{Na}^{+}>\mathrm{Rb}^{+}>\mathrm{Cs}^{+} \gg \mathrm{Li}^{+} \quad \mathrm{Ba}^{2+} \gg \mathrm{Sr}^{2+}, \mathrm{Ca}^{2+}>\mathrm{Mg}^{2+} \\
\mathrm{K}^{+}>\mathrm{Na}^{+}>\mathrm{Rb}^{+}>\mathrm{Cs}^{+}, \mathrm{Ba}^{2+} \gg \mathrm{Sr}^{2+}, \mathrm{Ca}^{2+}>\mathrm{Mg}^{2+}>\mathrm{Li}^{+}\end{array}$ \\
\hline Lasalocid A & $\begin{array}{ll}\mathrm{Rb}^{+}, \mathrm{Cs}^{+}, \mathrm{K}^{+}>\mathrm{Na}^{+}>\mathrm{Li}^{+} & \mathrm{Ba}^{2+} \gg \mathrm{Sr}^{2+}>\mathrm{Ca}^{2+}>\mathrm{Mg}^{2+} \\
\mathrm{Ba}^{2+} \gg \mathrm{Rb}^{+}, \mathrm{Cs}^{+}, \mathrm{K}^{+} \gg \mathrm{Sr}^{2+}>\mathrm{Ca}^{2+}>\mathrm{Mg}^{2+}>\mathrm{Na}^{+}>\mathrm{Li}^{+}\end{array}$ \\
\hline Lysocellin & $\begin{array}{l}\mathrm{K}^{+}>\mathrm{Rb}^{+}>\mathrm{Cs}^{+}>\mathrm{Na}^{+}>\mathrm{Li}^{+} \\
\mathrm{Ba}^{2+} \gg \mathrm{K}^{+}>\mathrm{Rb}^{+}>\mathrm{Cs}^{+}>\mathrm{Na}^{+}>\mathrm{Mg}^{2+}, \mathrm{Ca}^{2+}>\mathrm{Sr}^{2+}>\mathrm{Li}^{+}\end{array}$ \\
\hline $\mathrm{X}-14547 \mathrm{~A}$ & $\begin{array}{l}\mathrm{Rb}^{+}, \mathrm{Cs}^{+}, \mathrm{K}^{+}>\mathrm{Li}^{+}, \mathrm{Na}^{+} \\
\mathrm{Mg}^{2+}, \mathrm{Ca}^{2+}>\mathrm{Sr}^{2+}>\mathrm{Ba}^{2+}>\mathrm{Rb}^{+}, \mathrm{Cs}^{+}, \mathrm{K}^{+}>\mathrm{Li}^{+}, \mathrm{Na}^{2+}, \mathrm{Ca}^{2+}>\mathrm{Sr}^{2+}>\mathrm{Ba}^{2+}\end{array}$ \\
\hline
\end{tabular}

The cation selectivity sequence of lasalocid A, lysocellin and X-14547A was determined by the method described in Table 5 .

Fig. 3. Time course of $\mathrm{Ca}^{2+}$ and $\mathrm{Rb}^{+}$transport by antibiotic $\mathrm{X}-14766 \mathrm{~A}$ in a U-tube.

The U-tube system described by Ashton and STEINRAur ${ }^{11)}$ was employed for the assay. A glass U-tube was filled with $5 \mathrm{ml}$ of a chloroform solution of antibiotic X-14766A $\left(1 \times 10^{-4} \mathrm{M}\right)$. Two ml of an aqueous Tris$\mathrm{HCl}$ buffer $(20 \mathrm{~mm}, \mathrm{pH} 9.5)$ containing $1 \mathrm{~mm}\left[{ }^{45} \mathrm{Ca}\right]$ calcium chloride or $\left[{ }^{88} \mathrm{Rb}\right]$ rubidium chloride was placed in one arm of the U-tube, and an equal volume of the same buffer solution with unlabelled calcium or rubidium chloride in the other arm. The reaction was started by the addition of the respective labelled metal chloride, and the chloroform phase separating the two aqueous phases was then gently stirred with a magnetic stirrer. The rate of appearances of radioactive calcium or rubidium in the label-free side was determined by counting samples $(50 \mu \mathrm{l})$ taken from both aqueous phases with $10 \mathrm{ml}$ Aquasol (New England Nuclear, Boston, Mass.) in an intertechnique liquid scintillation spectrometer.

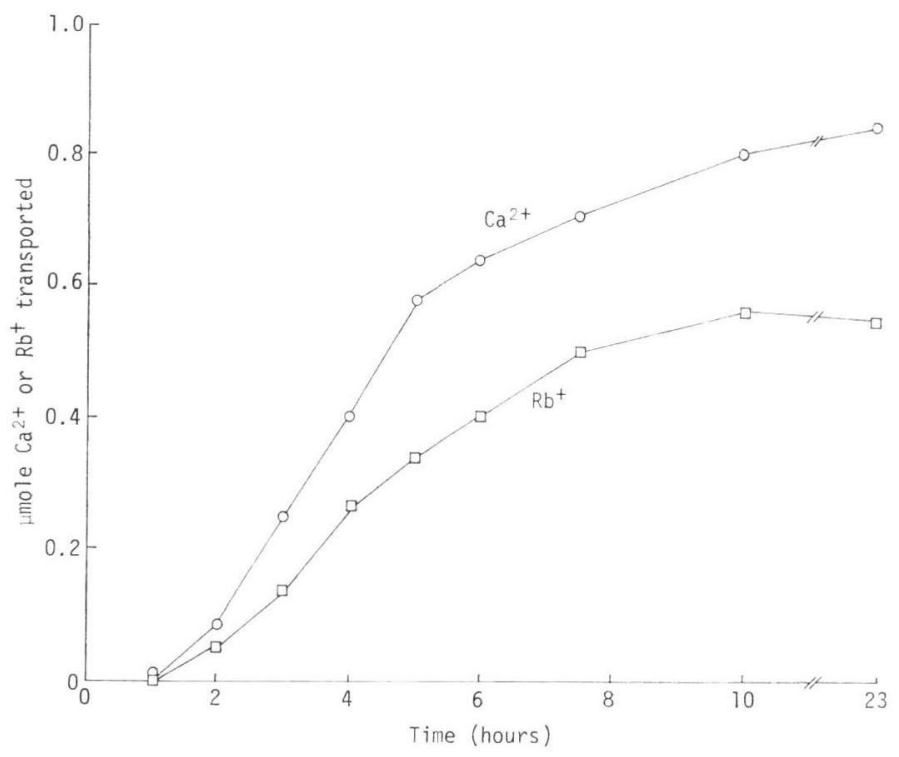

As an ionophore, X-14766A is capable of extracting monovalent and divalent metal cations from an aqueous solution into a non-miscible organic solvent ${ }^{8)}$. The cation selectivity sequence of $\mathrm{X}$ $14766 \mathrm{~A}$ as determined by an ion-competition experiment in a two-phase system (results shown in Table 5) is compared with that of other divalent cation ionophores, lasalocid $\mathrm{A}^{8)}$, antibiotic $\mathrm{X}-14547 \mathrm{~A}^{\text {9) }}$ and lysocellin ${ }^{10)}$ in Table 6. $\mathrm{X}-14766 \mathrm{~A}$ is also capable of transporting $\mathrm{Ca}^{2+}$ and $\mathrm{Rb}^{+}$across a solvent barrier $\left(\mathrm{CHCl}_{3}\right)$ from one aqueous phase to another as demonstrated in an experiment using a U-tube 
system of Ashton and Steinraur ${ }^{11)}$ (Fig. 3). These observations indicate that X-14766A is a broad cation selective ionophore. However, unlike the other divalent cation-binding monocarboxylic polyethers, the antibiotic binds most tightly with monovalent cations such as potassium; although it transports divalent cation (calcium) at a faster rate than monovalent cation (rubidium) across the chloroform barrier.

Acknowledgment

We would like to acknowledge Mr. George Higgins for technical assistance, Dr. Michael Kramer for the use of his scanning electron microscope, and Mr. RALPH EvANS for comparing the culture broths for antibiotic production. Thanks are also due to Drs. H. G. Luther, D. Siegel and the their staffs of Hoffmann-La Roche Inc. for the in vitro rumen fermentation and anti-anaerobic activity results.

\section{References}

1) Westley, J. W.; R. H. Evans, Jr., L. H. Sello, N. Troupe, C-m. Liu, J. F. Blount, R. G. Pitcher, T. H. Williams \& P. A. Miller: Isolation and characterization of the first halogen containing polyether antibiotic X-14766A, a product of Streptomyces malachitofuscus supsb. downeyi. J. Antibiotics 34:139 147,1981

2) Lechevalier, H. A.; M. P. Lechevalier \& N. N. Gerber: Chemical composition as a criterion in the classification of actinomycetes. Adv. Appl. Microbiol. 14: 47 72, 1971

3) Shirling, E. B. \& D. Gottlieb: Methods for characterization of Streptomyces species. Intern. J. Syst. Bacteriol. 16: 313 340, 1966

4) Gordon, R. E. \& M. M. SMith: Rapidly growing and fast bacteria. J. Bacteriol. 66: 41 48, 1953

5) Skerman, V. B. D.: A guide to identification of the genera of bacteria. The Williams and Wilkins Co., Baltimore, 1967

6) Buchanan, R. E. \& N. E. Gibbons (eds): Bergey's manual of determinative bacteriology, 8th edition. Williams and Wilkins Co., Baltimore, 1974

7) Richardson, L. F.; A. P. Raun, E. L. Potter, C. O. Cooley \& R. P. Rathmacher: Effect of monensin on rumen fermentation in vitro and in vivo. J. Animal Sci. 43: 657 664, 1976

8) Pressman, B. C.: Properties of ionophores with broad range cation selectivity. Fed. Proc. 32: 1698 1703,1973

9) Liu, C-M.; T. H. Hermann, M. Liu, D. N. Bull, N. J. Palleroni, B. La T. Prosser, J. W. Westley \& P. A. Miller: X-14547A, a new ionophorous antibiotic produced by Streptomyces antibioticus NRRL 8167. Discovery, fermentation, biological properties and taxonomy of the producing culture. J. Antibiotics 32: 95 99, 1979

10) Mitani, M.; T. Yamanishi, E. Ebata, N. ÖTake \& M. Koenuma: Studies on ionophorous antibiotics. VII. A broad cation selective ionophore, lysocellin. J. Antibiotics 30: 186 188, 1977

11) Ashton, R. \& L. K. Steinrauf: Thermodynamic consideration of the ion transport antibiotics. J. Mol. Biol. 49: $547 \sim 556,1970$

12) Liu, C-M. \& T. E. Hermann: Characterization of ionomycin as a calcium ionophore. J. Biol. Chem. 253: 5892 5894, 1978 